Review

\title{
Screening, Diagnostic and Prognostic Tests for COVID-19: A Comprehensive Review
}

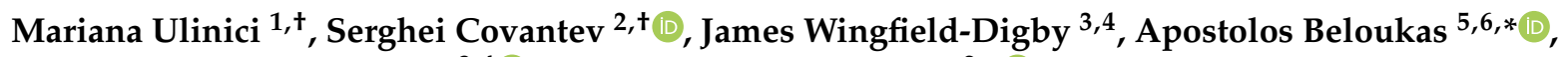 \\ Alexander G. Mathioudakis ${ }^{3,4}$ (D) and Alexandru Corlateanu ${ }^{2, *(\mathbb{D})}$
}

Citation: Ulinici, M.; Covantev, S.; Wingfield-Digby, J.; Beloukas, A.;

Mathioudakis, A.G.; Corlateanu, A. Screening, Diagnostic and Prognostic Tests for COVID-19: A

Comprehensive Review. Life 2021, 11,

561. https://doi.org/10.3390/

life11060561

Academic Editor: Patrick Mercié

Received: 21 May 2021

Accepted: 10 June 2021

Published: 14 June 2021

Publisher's Note: MDPI stays neutral with regard to jurisdictional claims in published maps and institutional affiliations.

Copyright: (C) 2021 by the authors Licensee MDPI, Basel, Switzerland. This article is an open access article distributed under the terms and conditions of the Creative Commons Attribution (CC BY) license (https:// creativecommons.org/licenses/by/ $4.0 /)$.
1 Department of Preventive Medicine, Discipline Microbiology and Immunology, State University of Medicine and Pharmacy "Nicolae Testemitanu", 2004 Chisinau, Moldova; mariana.ulinici@usmf.md

2 Department of Respiratory Medicine, State University of Medicine and Pharmacy "Nicolae Testemitanu", 2004 Chisinau, Moldova; kovantsev.s.d@gmail.com

3 Division of Infection, Immunity and Respiratory Medicine, School of Biological Sciences, The University of Manchester, Manchester Academic Health Science Centre, Manchester M23 9LT, UK; James.Digby@mft.nhs.uk (J.W.-D.); alexander.mathioudakis@manchester.ac.uk (A.G.M.)

4 The North West Lung Centre, Wythenshawe Hospital, Manchester University NHS Foundation Trust, Manchester M23 9LT, UK

5 Department of Biomedical Sciences, University of West Attica, 12243 Athens, Greece

6 Institute of Infection \& Global Health, University of Liverpool, Liverpool L69 7BE, UK

* Correspondence: abeloukas@uniwa.gr (A.B.); alexandru.corlateanu@usmf.md (A.C.)

+ These authors have contributed equally to the work.

\begin{abstract}
While molecular testing with real-time polymerase chain reaction (RT-PCR) remains the gold-standard test for COVID-19 diagnosis and screening, more rapid or affordable molecular and antigen testing options have been developed. More affordable, point-of-care antigen testing, despite being less sensitive compared to molecular assays, might be preferable for wider screening initiatives. Simple laboratory, imaging and clinical parameters could facilitate prognostication and triage. This comprehensive review summarises current evidence on the diagnostic, screening and prognostic tests for COVID-19.
\end{abstract}

Keywords: SARS-CoV2; COVID-19; coronavirus; diagnosis; screening; prognosis; PCR; CRISP; immunoglobulin

\section{Introduction}

Declared a pandemic in March 2019, COVID-19, which is caused by the novel severe acute respiratory coronavirus 2 (SARS-CoV-2) has caused not only significant global morbidity (>160 million cases) and mortality (>3.4 million deaths), but also disruption to society and economies [1-4]. The true incidence of COVID-19 is likely to have been underestimated, either due to individuals underreporting mild symptoms or inadequate testing. Screening and diagnostic strategies for COVID-19 have varied worldwide according to government policies, technology, funding, and data management capabilities. Even in industrialised nations, uncertainties in strategy, regulatory hurdles and supply issues have disrupted testing capabilities, possibly contributing to worsening spread of SARS-CoV2. Standardisation and improvement of COVID-19 diagnostics, with more efficient detection and treatment of cases, is likely to be beneficial to both industrialised and low-income nations [5-7]. In this review, we address some of the key concerns regarding laboratory and radiological screening, diagnosis and prognostication that have arisen during the ongoing COVID-19 pandemic [8]. A detailed description of the characteristics of the available screening and diagnostic assays and medical devices is beyond the scope of this manuscript and can be found in the Joint Research Centre of the European Medicines Agency/European Commission (https: / / covid-19-diagnostics.jrc.ec.europa.eu/devices, accessed on 10 June 2021). 


\section{Diagnostic Testing}

Confirming diagnosis, starting treatment (where necessary) and initiation of socialdistancing measures are essential in the management of COVID-19. Numerous methods are utilised for the laboratory diagnosis of viral infections, such as culture, viral nucleic acid detection and serology (i.e., viral antigen or humoral responses) [9]. The most commonly available tests are direct (detection of nucleic acids (i.e., viral genome) or antigens of the virus) and indirect (assessment of serum antibody levels).

\subsection{Direct Testing-Molecular Methods}

Viral nucleic acid detection, directly detecting genetic material, is the gold standard in diagnostic virology [9]. Two commonly preferred nucleic acid-based detection methodologies are available for the diagnosis of SARS-CoV-2. RT-PCR based methods (real-time polymerase chain reaction (RT-PCR)) are routinely used for diagnosis, while high throughput genome sequencing is used at an unprecedented rate for COVID-19 variants surveillance [10].

RT-PCR has frequently been utilised in the detection of COVID-19 nucleic acids from a number of sources such as posterior oropharyngeal saliva, throat and nasopharyngeal swabs, sputum and bronchial fluid [11]. Moreover, in some cases the virus can be isolated from blood, semen and faeces, even in the absence of a positive respiratory sample [12]. However, a recent systematic review concluded that RT-PCR tests from stool, urine, and plasma were less sensitive than respiratory samples [13].

In spite of RT-PCR being the benchmark for COVID-19 diagnosis, there is a potential for false-negative results, which may be related to the viral load, sampling time or sampling bias. RT-PCR tests typically provide a positive result if the specimen is collected 2-8 days after the onset of the infection [14]. A meta-analysis, which assessed the accuracy of COVID-19 tests and included 34 studies with 12,057 COVID-19 confirmed cases reported false-negative RT-PCR rates between $2 \%$ and $29 \%$. The reported sensitivity was $71-98 \%$, based on individuals with an initial negative RT-PCR being subsequently found to have a positive one. COVID-19 diagnostic accuracy may be improved by combining results of RT-PCR, imaging and serology screening [13].

Several other methods, namely, droplet digital PCR (ddPCR) and reverse transcriptionloop-mediated isothermal amplification (RT-LAMP), which detect SARS-CoV-2 RNA are being also used to complement RT-PCR. Overall, ddPCR performs better than standard RT-PCR for clinical diagnosis of SARS-CoV-2, reducing false-negative results, although it is less thoroughly evaluated compared to the latter $[15,16]$. This is further highlighted by evidence showing the ddPCR-based can effectively detect SARS-CoV-2 genome in symptomatic cases with a negative standard RT-PCR [17]. A recently published study reported that combining RT-PCR with ddPCR improves the sensitivity from $40 \%$ (95\% CI: $27-55 \%$ ) to $94 \%$ (95\% CI: $83-99 \%$ ) without limiting the specificity, which remains $100 \%$ (95\% CI: $48-100 \%)$, leading to an overall increase in the diagnostic accuracy from $47 \%$ (95\% CI: $33-60 \%)$ to $95 \%$ (95\% CI: 84-99\%) [16].

Rapid diagnosis of COVID-19 is important, and some methods provide a result in less than an hour. RT-LAMP detects SARS-CoV-2 RNA in approximately 30 min with good correlation to the conventional RT-PCR, allowing for rapid delivery of results to patients both in the hospital and community settings [18]. RT-LAMP has been reported to have high sensitivity and specificity, operational simplicity and low cost [19].

Data on analytical performance (i.e., sensitivity, specificity, lower limits of detection (LOD), etc.) for all commercially available molecular assays are provided by FIND (a global alliance for diagnostics, which seeks to ensure equitable access to reliable diagnosis around the world) and can be assessed in the following directory, which is regularly updated (https:/ / www.finddx.org/test-directory/, accessed on 10 June 2021).

Alternative approaches based on combinations of isothermal amplification and clustered regularly interspaced short palindromic repeats (CRISPR) such as the SHERLOCK (specific high-sensitivity enzymatic reporter unlocking) technique reduce dependence on 
RT-qPCR equipment [20]. SHERLOCK was found to be $98.5 \%$ specific and $93.1 \%$ sensitive with a lateral-flow readout [20]. The fluorescence readout was 100\% specific and $96 \%$ sensitive for the full range of viral load in the clinical samples. In 380 SARS-CoV-2-negative samples obtained prior to surgery, SHERLOCK matched quantitative PCR with reverse transcription in $100 \%$ of cases [21,22]. However, data on RT-LAMP and CRISPR are significantly more limited than on PCR methods. Further validation is required. A comparison of the molecular-based direct diagnostic methods is shown in Table 1. 
Table 1. Comparison of molecular diagnostic tests.

\begin{tabular}{|c|c|c|c|c|c|c|c|}
\hline Method & Biomarker & Description & Type of Clinical Sample & Operating Temperature & Assay Time & Advantages & Limitations \\
\hline RT PCR & $\begin{array}{c}\text { Nucleic acid } \\
\text { (SARS-CoV-2 RNA) }\end{array}$ & $\begin{array}{ll}- & \text { Regular real time } \\
& \text { PCR } \\
- & \text { Gold Standard }\end{array}$ & Respiratory specimens & Thermal cycling & $2-4 \mathrm{~h}$ & $\begin{array}{l}\text { - } \quad \begin{array}{l}\text { High performance } \\
\text { characteristics }\end{array}\end{array}$ & $\begin{array}{ll}\text { - } & \text { Require equipment, } \\
& \text { resources, and expertise } \\
\text { - } & \text { Risk of cross } \\
\text { contamination. }\end{array}$ \\
\hline ddPCR & $\begin{array}{c}\text { Nucleic acid } \\
\text { (SARS-CoV-2 RNA) }\end{array}$ & $\begin{array}{ll}- & \text { Droplet digital PCR } \\
- & \text { Limited dilution; } \\
\text { probability } \\
\text { theory-based } \\
\text { analysis. }\end{array}$ & Throat swab & Thermal cycling & $1 \mathrm{~h}$ & $\begin{array}{ll}\text { - } & \text { High sensitivity in low } \\
\text { viral load specimens }\end{array}$ & $\begin{array}{ll}\text { - } & \text { Less affordable than } \\
\text { RT-PCR. } \\
\text { - } \quad \text { Require specialised } \\
\text { equipment and } \\
\text { consumables. }\end{array}$ \\
\hline RT-LAMP & $\begin{array}{c}\text { Nucleic acid } \\
\text { (SARS-CoV-2 RNA) }\end{array}$ & $\begin{array}{ll}- & \text { Isothermal } \\
- & \text { Single step RNA } \\
& \text { reverse } \\
\text { transcription and } \\
\text { nucleic acid } \\
\text { amplification. }\end{array}$ & Throat swab & $30-65^{\circ} \mathrm{C}$ & $30 \mathrm{~min}$ & $\begin{array}{ll}\text { - } & \text { High sensitivity and } \\
\text { specificity.Uses simple } \\
\text { instruments. } \\
\text { Does not require thermal } \\
\text { cycling (and is therefore } \\
\text { rapid and affordable). } \\
\text { - Uses simple instruments. }\end{array}$ & $\begin{array}{l}\text { Challenges in generating } \\
\text { sequence specific primers. } \\
\text { However, commercially } \\
\text { assays are now available. } \\
\text { An internal PCR inhibition } \\
\text { control cannot be included, } \\
\text { and therefore duplication } \\
\text { of reactions is needed. }\end{array}$ \\
\hline $\begin{array}{c}\text { CRISPR } \\
\text { (SHERLOCK) }\end{array}$ & $\begin{array}{c}\text { Nucleic acid } \\
\text { (SARS-CoV-2 RNA) }\end{array}$ & $\begin{array}{ll}\text { - } & \text { CRISPR/Cas13 } \\
\text { based nucleic acid } \\
\text { detection method } \\
\text { - } \\
\text { Qualitative visual } \\
\text { results. }\end{array}$ & Nasopharyngeal swabs & & $<1 \mathrm{~h}$ & $\begin{array}{ll}- & \text { Low cost } \\
- & \text { Higher sensitivity } \\
- & \text { Uses simple instruments. }\end{array}$ & $\begin{array}{l}\text { - Cas13 does not } \\
\text { catalytically activate when } \\
\text { there are two or more } \\
\text { mistakes in the crisper } \\
\text { RNA: target duplex } \\
\text { - Suboptimal quantification }\end{array}$ \\
\hline $\begin{array}{c}\text { CRISPR } \\
\text { (DETECTR) }\end{array}$ & $\begin{array}{c}\text { Nucleic acid } \\
\text { (SARS-CoV-2 RNA) }\end{array}$ & $\begin{array}{ll}- & \text { RT-LAMP } \\
- & \text { CRISPR } \\
& \text { Cas12-based lateral } \\
& \text { flow assay }\end{array}$ & Respiratory specimens & $\begin{array}{ll}- & \mathrm{C} 62^{\circ} \mathrm{C} \text { for RT } \\
- & \text { LAMP } \\
- & 37^{\circ} \mathrm{C} \text { for } \\
& \text { CRISPR-Cas12 }\end{array}$ & $<40 \min$ & $\begin{array}{ll}- & \text { Rapid } \\
- & \text { Easy to implement } \\
- & \text { High sensitivity and } \\
& \text { specificity }\end{array}$ & $\begin{array}{ll}\text { - } & \text { Risk of } \\
\text { cross-contamination or } \\
\text { suboptimal sample } \\
\text { preparation, limiting } \\
\text { accuracy. }\end{array}$ \\
\hline
\end{tabular}


Efficient testing in COVID-19 is important but the time in which results are generated varies significantly, not only with choice of molecular tests, but also due to an array of factors not limited to transportation, processing and reporting [8]. Speed of results could certainly be improved with better test-to-laboratory and results to clinician pathways, but improving the efficiency of these steps is not always straightforward. The COVID-19 pandemic has however highlighted the importance of low-cost rapid point of care (POC) virology diagnostics [19].

Of the hundreds of SARS-CoV-2 diagnostic test assays under development or in use, syndromic testing is of particular interest in tackling the pandemic. This is the process of simultaneously targeting and detecting multiple pathogens that cause similar signs and symptoms, especially during the winter season when multiple different viruses could be circulating.

Syndromic respiratory testing, such as the Multiplex RT-PCR tests that detect multiple respiratory viruses in the same specimen including SARS-CoV-2, influenza, and 21 other common respiratory viral and bacterial pathogens have huge potential to streamline diagnosis and early disease specific treatment $[23,24]$. An added benefit is the speed in which syndromic tests return.

There is still a role for single COVID-19 tests, when pre-test probability is high or contact tracing is required. On the over hand, syndromic tests are extremely useful when symptoms are non-specific, and the list of possible diagnoses is long. Similarly, diagnostic accuracy is more important in patients with moderate or severe disease, as SARS-CoV2 management (dexamethasone, anti-virals, immunomodulatory treatments), differs significantly to that of alternative conditions.

\subsection{Direct Testing-Antigen Testing}

Antigen tests can detect the presence of SARS-CoV-2 viral proteins in nasal or pharyngeal swabs and saliva. Most are lateral-flow chromatographic immunoassays (point of care, rapid detection) or chemiluminescence immunoassays (laboratory-based). Although direct antigen tests are increasingly used, the diagnostic accuracy of these tests is lower in comparison with that of RT-PCR [25]. There are some concerns regarding their specificity, since they may cross-react with other coronaviruses, but the main issue is their sensitivity [26]. The sensitivity of such panels ranges between $34 \%$ and $88 \%$, based on the findings of a Cochrane systematic review [25,27]. Therefore, despite the higher accuracy of positive results, negative results should be treated more cautiously. Their diagnostic accuracy is greatest in symptomatic patients, when the viral load in the nasopharynx is higher, enabling early diagnosis, triage and treatment [28]. The optimum timing of testing can vary (within 5, 7 and 12 days from symptom onset) [29]. Therefore, the advantages of point of care tests, with rapid identification and isolation of cases, at a lower cost to RT-PCR tests, may perhaps be limited to some extent by the poor sensitivity they offer, especially in asymptomatic or pre-symptomatic individuals. Despite these limitations, the main advantages of antigen tests are speed (usually around 5-30 min compared with hours for PCR-based techniques), ease of interpretation and the limited technical skill and infrastructure required. This is particularly important for resource-limited settings [30]. In balance, it has been proposed that rapid and real-time viral antigen detection assays have been shown to be more useful in controlling the spread of the infection than more sensitive, but more expensive tests with more prolonged test time, such as the molecular tests [14].

\subsection{Indirect Testing}

Serological testing is an alternative means of diagnosing COVID-19. Whereas in most infections the IgM response precedes IgG, the distinction in COVID-19 (where both can be detected in the initial weeks) is less clear. This explains the similarities in the pooled sensitivity of both IgM and IgG in the early weeks of COVID-19 infection-33\% and 23\% at one week and $73 \%$ and $68 \%$ at two weeks, respectively [31]. At three to four weeks the picture begins to change, with IgG or total antibody tests providing the greatest sensitivity 
(low false-negative results) and specificity (low false-positive results) compared to other antibody types [31].

Several methods have been proposed for accurate assessment of IgG and IgM antibodies such as ELISA, lateral flow immunoassay-based Kits (LFIA) and chemiluminescence immunoassay-based Kits (CLIA) [32-34].

In a meta-analysis of COVID-19 serology tests that included 40 studies, the pooled sensitivity of IgG or IgM ELISA was $84.3 \%$ (95\% confidence interval, $75.6 \%$ to $90.9 \%$ ), for LFIAs it was $66.0 \%$ (49.3\% to $79.3 \%$ ), and for CLIAs it was $97.8 \%(46.2 \%$ to $100 \%)$. Among LFIAs, the pooled sensitivity of commercial kits was $65.0 \%$ (49.0\% to $78.2 \%)$, which was lower than that of non-commercial tests, $88.2 \%$ ( $83.6 \%$ to $91.3 \%$ ).

Sensitivity was higher from three weeks after symptom onset (ranging from 69.9\% to $98.9 \%$ ) compared to within the first week (13.4\% to 50.3\%) [35]. The specificity of the evaluated assays was less variable and ranged between $96.6 \%$ to $99.7 \%$. However, heterogeneity was observed in all analyses and methodological issues, such as patients' selection bias, were identified across most of the studies included in this meta-analysis [36].

False-positive serological testing results have been associated with the presence of other viral infections (cytomegalovirus) or autoimmune diseases (such as scleroderma or systemic lupus erythematosus) $[37,38]$.

\subsection{Conventional Diagnostic Approaches}

\subsubsection{Clinical Presentation}

The most frequent symptoms of COVID-19 at presentation are cough (67.8\%), fever (43.8\%), and breathlessness (18.7\%) [39]. Signs and symptoms in COVID-19 are however not specific and are often indistinguishable from those of other respiratory viruses. Even lack of smell or loss of taste are not specific for COVID-19 and can be easily confused with almost any other viral respiratory disease, which may also be endemic during winter period.

Clinical symptoms are not a reliable way of diagnosing COVID-19 patients except for patients with recent COVID-19 contact. Where there is significant transmission within a region or country, monitoring the number of healthcare consultations for COVID-19 compatible symptoms and establishing a diagnosis (including alternatives such as influenza and acute bacterial respiratory infection) helps identify further cases for testing (robust syndromic surveillance).

\subsubsection{Pulse Oximetry}

Pulse oximetry is a simple and accessible tool for screening and continuous monitoring of patients with COVID-19. The target oxygen saturation range for patients with COVID19 without comorbidities such as chronic obstructive pulmonary disease (COPD) is 92$96 \%[3,4,40]$. The test is particularly useful in COVID-19 as patients can have severe hypoxemia in the absence of dyspnoea, sometimes referred to as "silent hypoxemia". Home monitoring of patients with COVID-19, with patients only being admitted to hospital if the oxygen saturations decline below $92 \%$, has been a valuable tool to reduce admissions and provide safe monitoring in the community [41,42]. Severe COVID-19 is suggested by oxygen saturation levels $<92 \%$ ( $<88 \%$ in COPD) on room air, while in the absence of hypoxaemia most patients can be monitored at home [43].

Home $\mathrm{SpO} 2<92 \%$ was linked to a greater risk of intensive care unit admission, acute respiratory distress syndrome (ARDS) and septic shock. Therefore, a SpO2 cutoff of $92 \%$ was found to be a useful an indicator for readmission [44].

Initial oxygen saturation measured by ambulance staff in patients with COVID19 patients correlate well with short-term (30-day) patient mortality or ICU admission. Even small deviations in oxygen saturation of $1-2 \%$ below $96 \%$ confer an increased mortality risk [45]. 


\subsubsection{Hematological Evaluation}

Thrombocytopenia, leukopenia and neutropenia can all be seen in COVID-19 disease $[39,46]$. Lymphopenia $(89.2 \%)$ is the most common finding on a full blood count (FBC), followed by neutrophilia (74.3\%), and thrombocytopenia (24.3\%) [47]. Lymphopenia and eosinopenia were also associated with severe disease and mortality and they were identified in $77.6 \%$ and $81.2 \%$ of non-survivors [48-50]. Although FBC patterns cannot be used for diagnosis alone, they can assist in triage and prognostication.

Several indices based on FBC variables have been developed to help guide COVID-19 diagnosis, prognostication and triage (Table 2). Systemic inflammation index (SII) is a biomarker predictive of in-hospital mortality and the development of ARDS [51].

Table 2. Inflammation indices related to mortality in COVID-19 [49].

\begin{tabular}{|c|c|c|}
\hline Index & Formula & $\begin{array}{l}\text { Optimal Cutoff Values and } \\
\text { Performance Characteristics }\end{array}$ \\
\hline SII & $\begin{array}{c}\text { platelet } \times \\
\text { neutrophil/lymphocyte } \\
\text { counts }\end{array}$ & $\begin{array}{c}\text { Cut off point }>1835 \text { sensitivity } 55 \% \\
\text { specificity } 75 \%\end{array}$ \\
\hline SIRI & $\begin{array}{c}\text { neutrophil } \times \\
\text { monocyte/lymphocyte }\end{array}$ & $\begin{array}{c}\text { Cut off point }>2.93 \text { sensitivity } 59 \% \\
\text { specificity } 74 \%\end{array}$ \\
\hline AISI & $\begin{array}{l}\text { neutrophil } \times \text { platelet } \times \\
\text { monocyte/lymphocyte }\end{array}$ & $\begin{array}{c}\text { Cut off point }>798 \text { sensitivity } 59 \% \\
\text { specificity } 72 \%\end{array}$ \\
\hline NLR & neutrophil/lymphocyte ratio & $\begin{array}{c}\text { Cut off point }>15.2 \text { sensitivity } 38 \% \\
\text { specificity } 97 \%\end{array}$ \\
\hline NLPR & $\begin{array}{c}\text { neutrophil/(lymphocyte } \times \\
\text { platelet) }\end{array}$ & $\begin{array}{c}\text { Cut off point }>0.019 \text { sensitivity } 66 \% \\
\text { specificity } 75 \%\end{array}$ \\
\hline dNLR & $\begin{array}{l}\text { neutrophils/(white blood } \\
\text { cells -neutrophils) }\end{array}$ & $\begin{array}{c}\text { Cut off point }>6.2 \text { sensitivity } 52 \% \\
\text { specificity } 85 \%\end{array}$ \\
\hline
\end{tabular}
AISI—index of systemic inflammation, NLR—-neutrophil to lymphocyte ratio, NLPR-neutrophil to lympho-
cyte $\times$ platelet ratio, NLR—neutrophil to lymphocyte ratio, SII—systemic inflammation index, SIRI—systemic inflammation response index.

Non-survivors had significantly higher index of systemic inflammation (AISI), derived neutrophil to lymphocyte ratio (dNLR), neutrophil to lymphocyte $\times$ platelet ratio (NLPR), neutrophil to lymphocyte ratio (NLR), systemic inflammation index (SII), and systemic inflammation response index (SIRI) values when compared to survivors. All of these indices are calculated based on FBC and their comparison is presented in Table 2. KaplanMeier survival curves showed significantly lower survival in patients with higher AISI, dNLR, MLR, NLPR, NLR, SII, and SIRI. However, after adjusting for confounders, SII was best at predicting survival [52].

Some of these inflammatory markers may also have a diagnostic value. Lymphopenia is suggestive of COVID-19 in patients with consistent clinical presentation and imaging. Moreover, it seems that most patients have a high NLR of $>5$ (94.5\%), high SII index of $>500(89.2 \%)$, increased C-reactive protein $(100 \%)$ and high level of IL6 $(>10 \mathrm{pg} / \mathrm{mL})$ [47].

Since the pathogenesis of COVID-19 is tightly linked to pro-inflammatory state and cytokine storm, several interleukins (IL) have been evaluated as diagnostic and prognostic markers. Baseline changes in IL-6, IL-10 and their ratio may be a good prognostic marker [53]. Studies have shown that IL-6 correlates with clinical outcomes, such as mortality and respiratory failure better than laboratory alternatives such as CRP, ferritin and liver enzymes [54,55]. A comparison of the inflammatory markers is presented in Table 3. 
Table 3. Inflammatory biomarkers.

\begin{tabular}{|c|c|c|}
\hline Marker/Score & Applicability & Reference \\
\hline CRP & $\begin{array}{c}\text { Detection of severe/critical illness: Threshold: } \\
\text { 41.4; Sensitivity: } 90.5 \% \text {; specificity: } 77.6 \% \\
\text { Positive predictive value: } 61.3 \% \text {; Negative } \\
\text { predictive value: } 95.4 \%\end{array}$ & [56] \\
\hline IL-6 & $\begin{array}{l}\text { In-hospital mortality: Threshold: } 37.65 \mathrm{pg} / \mathrm{mL} \text {; } \\
\text { Sensitivity: } 91.7 \% \text {; Specificity: } 95.7 \% \text {. } \\
\text { Rise in IL-6 from presentation to day } 4 \text { was } \\
\text { predictive of a more severe clinical outcome (OR } \\
1.14,95 \% \text { CI 1.07-1.21, per } 10 \text { units increase) }\end{array}$ & {$[53,57]$} \\
\hline IL-6:IL-10 ratio & $\begin{array}{c}\text { Rise in IL-6/IL-10 ratio from presentation to day } \\
4 \text { was predictive of increased risk of a more } \\
\text { severe clinical outcome (OR } 1.28,95 \% \text { CI } \\
1.17-1.40 \text {, per } 0.1 \text { units increase) }\end{array}$ & [53] \\
\hline Dublin-Boston score & $\begin{array}{l}\text { Calculated by multiplying the day } 0 \text { to day } 4 \\
\text { change in IL-6:IL- } 10 \text { ratio by two, rounding to } \\
\text { whole numbers, and then restricting the score to } \\
\text { a } 5 \text {-point scale ranging from }-2 \text { to } 2 \text {. Rise in the } \\
\text { Dublin-Boston score was predictive of a more } \\
\text { severe outcome (OR } 5.62,95 \% \text { CI }-3.22-9.81, \mathrm{p}= \\
1.2 \times 10^{-9} \text {, per } 1 \text { point increase) }\end{array}$ & [53] \\
\hline
\end{tabular}

The concept of cytokine storm has been recently reappraised. A recent systematic review and meta-analysis based on 25 studies has reviewed the role of IL-6 in patients with severe or critical disease. Patients with COVID-19 $(n=1245$ patients) were compared to patient with sepsis $(n=5320)$, cytokine release syndrome $(n=72)$, and acute respiratory distress syndrome unrelated to COVID-19 $(n=2767)$. Mean interleukin- 6 concentrations were nearly 100 times greater in patients with cytokine release syndrome, 27 times higher in patients with septic shock, and 12 times higher in patients with ARDS unrelated to COVID19 [58]. This data does not support the concept of a COVID-19-induced organ dysfunction.

Serum levels of IL- 6 and IL-10 are also strong predictors of disease progression and severity [59]. Being inexpensive, they can be performed on arrival to hospitals or care centers with minimum facilities. Using these tests, earlier identification of patients at risk of severe disease may be possible.

\subsubsection{Coagulation}

Coagulation dysfunction is a risk factor for adverse outcomes in COVID-19 and should be carefully considered in caring for patients [60]. Thrombocytopenia is detected in more than a half of the patients and its incidence varies according to disease severity. It is typically mild $\left(100-150 \times 10^{9} / \mathrm{L}\right)$ [61]. Although non-diagnostic, platelet counts and coagulation markers provide valuable information.

In one study, coagulation function in COVID-19 was assessed with thrombin- antithrombin complex (TAT), $\alpha$ 2-plasmininhibitor-plasmin complex (PIC), thrombomodulin (TM), t-PA/PAI-1 complex (t-PAIC), prothrombin time (PT), international normalised ratio (INR), activated partial thromboplastin time (APTT), fibrinogen (FIB), thrombin time (TT), D-Dimer (DD), and platelet (PLT). The levels of TAT, PIC, TM, t-PAIC, PT, INR, FIB, and DD in COVID-19 patients were higher than healthy controls $(p<0.05)$ and in those with thrombotic disease than without thrombotic disease $(p<0.05)$. Patients with thrombotic disease had a higher case-fatality $(p<0.05)$. TAT, PIC, TM, t-PAIC, PT, INR, APTT, FIB, DD, and PLT also correlated with disease severity. T-PAIC and DD were independent risk factors for death and accurately predicted COVID-19 mortality risk [62-64]. Since a coagulation panel is a standard procedure, it is useful to assess several parameters that can indicate severity of the disease and a risk of thrombosis (Table 4). 
Table 4. Coagulation parameters helpful in COVID-19 triage.

\begin{tabular}{|c|c|c|}
\hline Tests & Impact & Reference \\
\hline $\mathrm{DD}$ & $\begin{array}{l}\text { In-hospital mortality. Threshold: } 2.0 \mu \mathrm{g} / \mathrm{mL} \text {; } \\
\text { Sensitivity: } 92.3 \% \text {; Specificity: } 83.3 \% \text {. }\end{array}$ & [63] \\
\hline t-PAIC & $\begin{array}{l}\text { In-hospital mortality. Threshold: } 20.6 \mathrm{ng} / \mathrm{mL} \text {; } \\
\text { Sensitivity: } 90.0 \% \text {; Specificity: } 91.2 \% \text {. }\end{array}$ & [64] \\
\hline PT & $\begin{array}{l}\text { In-hospital mortality. Prolonged prothrombin } \\
\text { time was predictive of mortality (OR: } 2.19,95 \% \\
\text { CI: } 1.29-3.73 \text { ). }\end{array}$ & [65] \\
\hline FIB & $\begin{array}{c}\text { Development of ARDS. Threshold: } 617 \mathrm{mg} / \mathrm{dL} \text {; } \\
\text { Sensitivity: } 76 \% \text {; Specificity: } 79 \% \text {. }\end{array}$ & [66] \\
\hline PLT & $\begin{array}{c}\text { Mortality: Elevating platelet counts are } \\
\text { predictive of decreased mortality. } 50 \times 10^{9} / \mathrm{L} \\
\text { increment increase in platelets was associated } \\
\text { with } 40 \% \text { decrease in mortality. Among } \\
\text { hospitalised patients, the platelet trajectory } \\
\text { (increase or decrease) during hospital stay, was } \\
\text { associated with decreased or increased mortality, } \\
\text { respectively. }\end{array}$ & [67] \\
\hline ISTH criteria of DIC & $\begin{array}{l}\text { DIC is strongly associated with mortality. } 71.4 \% \\
\text { of non-survivors fulfilled the ISTH criteria for } \\
\text { overt DIC ( } \geq 5 \text { points) in the later stages of } \\
\text { coronavirus pneumonia, while the respective } \\
\text { proportion among survivors was } 0.6 \% \text {. }\end{array}$ & [68] \\
\hline
\end{tabular}

\subsubsection{Comorbidities}

Comorbid conditions often present a risk factor for adverse outcomes in infectious diseases. Numerous comorbidities have been correlated with adverse outcomes of COVID19. However, COVID-19 outcomes are strongly correlated with age and gender, and most studies evaluating prognostic factors have not adequately accounted for these confounders. However, a recent meta-analysis using age and gender adjusted data confirmed strong associations between co-existing diseases such as chronic heart failure, ischemic heart disease, chronic obstructive pulmonary disease, diabetes mellitus, hypertension, malignancy, end-stage renal disease, dementia and obesity and increased COVID-19 related mortality [69].

A retrospective cohort study of 31,461 adults with COVID-19 from 24 healthcare organisations in the US demonstrated a high burden of comorbidities. Those most commonly listed were chronic obstructive pulmonary disease (COPD) (17.5\%) and type 2 diabetes $(15 \%)$. Using multivariate logistic regression analysis, higher odds of mortality with COVID-19 was seen across a range of conditions including dementia (OR 1.29), myocardial infarction (OR 1.97), cardiac failure (OR 1.42), COPD (OR 1.24), moderate to severe liver disease (OR 2.62), renal disease (OR 2.13) and metastatic malignancy (OR 1.70) [70]. This study highlights the need to have low clinical suspicion of COVID-19 in patients with multiple co-morbidities and to screen for moderate to severe disease early in the disease course.

Charlson comorbidity index (CCI), Elixhauser (ECI), and age- and smoking-adjusted Charlson (ASCCI) and Elixhauser (ASECI) comorbidity indices have also been used to predict COVID-19 outcomes. Patients with higher indices had a significantly longer time of hospitalisation (more than 24 days). CCI score $>2$ had a sensitivity of $79 \%$ and specificity of $71.9 \%$ for predicting longer time of hospitalisation, while ASCCI $>3$ had a sensitivity of $57.9 \%$ and specificity of $96.9 \%$, and ASECI score $>5$ had a specificity of $57.9 \%$ and sensitivity of $90,6 \%$. Using these scores, it may be possible to identify cases with potential for severe 
disease, and therefore a poorer prognosis earlier, allowing better treatment planning and communication [71].

Per point increase of CCI score is associated with an increased mortality risk of $16 \%$. A higher mean CCI score is also significantly associated with mortality and disease severity. CCI score should be utilised for risk stratifications of hospitalised COVID-19 patients [72].

Vitamin D deficiency represents a well-established modifiable risk factor for severe COVID-19 disease and COVID-19 related mortality [73]. There is preliminary evidence suggesting that Vitamin D replacement could protect from COVID-19 contraction or adverse outcomes $[73,74]$.

On the other hand, other comorbidities, such as asthma [75-77], urticaria and erythema nodosum [78] have been associated with decreased risk of adverse COVID-19 outcome. However, these diseases often affect younger people, who are anyway less prone to COVID19 adverse outcomes, and therefore, the observed protective effect might be the result of confounding [69].

\subsubsection{Diagnostic Nomogram}

Comorbid conditions often present a risk factor for adverse outcomes in infectious diseases. Numerous comorbidities have been correlated with adverse outcomes of COVID-19.

Several parameters such as older age, higher serum lactate dehydrogenase (LDH), CRP, coefficient of variation of red blood cell distribution width (RDW), direct bilirubin (DBIL), blood urea nitrogen (BUN), and lower albumin on admission have been correlated with higher odds of severe COVID-19. Therefore, they were used to elaborate a prognostic nomogram composed of seven features for early identification of patients at risk of exacerbation to severe COVID-19. The generated nomogram was efficient for early identification of severe COVID-19 in the training cohort (AUC 0.912 (95\% CI 0.846-0.978), sensitivity $85.71 \%$, specificity $87.58 \%)$; and in the validation cohort $(0.853(0.790-0.916), 77.5 \%, 78.4 \%)$ [79]. This diagnostic nomogram is assessed based on the admission laboratory tests.

\subsubsection{Imaging}

A recent meta-analysis of 34 studies with 9339 patients with SARS-CoV-2 infection, confirmed using RT-PCR alone or RT-PCR with another test, assessed the diagnostic efficiency of chest X-ray (CXR), computed topography (CT) and ultrasound (USS). COVID19 was correctly diagnosed based on CT thorax in $89.9 \%$ of patients with COVID-19 and incorrectly identified in $38 \%$ of patients who did not have COVID-19. The sensitivity of CXR ranged between 57-89\%, while false-positive results ranged between $11-89 \%$ of patients without COVID-19. Finally, the sensitivity of lung ultrasound was $96 \%$, while the corresponding false-positive rate was $38 \%$. These findings demonstrate that chest imaging modalities are sensitive in identifying COVID-19 with lower respiratory tract involvement, while their specificity is limited [80]. Interestingly, inter-rater agreement on the interpretation of chest $x$-rays is moderate $[81,82]$.

Pre-operative CT chest has been successfully and widely used as a screening tool for COVID-19 in people undergoing surgical procedures during the pandemic [83].

\section{Conclusions}

Molecular testing with RT-PCR is the gold-standard not only for screening and diagnosis of COVID-19, but also to follow-up disease progression. However, more affordable, direct antigen or indirect antibody COVID-19 tests, despite their more limited sensitivity, might be more cost-effective screening modalities. Selection of the optimal strategies for COVID-19 screening, diagnosis and prognostication amidst the pandemic is complex. Unfortunately, the vast costs associated with these processes during the pandemic limit equity globally and national strategies need to be informed by best available evidence, but also by economics. Prediction models based on simple laboratory tests, imaging and clinical variables can facilitate cost-effective prognostication and triage. 
Further research is needed to develop accurate and affordable screening and diagnostic strategies, as well as accurate prognostic tools to facilitate identification of patients at risk of deterioration and resource allocation.

Author Contributions: A.B., A.G.M. and A.C. contributed to the study conception. M.U., S.C., J.W.-D. and A.C. prepared the initial draft of this review. All authors contributed to critical revision of the paper for intellectual content. All authors have read and agreed to the published version of the manuscript.

Funding: This research received no external funding.

Institutional Review Board Statement: Not applicable.

Informed Consent Statement: Not applicable.

Data Availability Statement: Not applicable.

Acknowledgments: J.W.-D. and A.G.M. were supported by the National Institute for Health Research Manchester Biomedical Research Centre (NIHR Manchester BRC).

Conflicts of Interest: All authors have completed the ICMJE uniform disclosure form and declare no conflicts related to the submitted work.

\section{References}

1. NEJM. Dying in a Leadership Vacuum. N. Engl. J. Med. 2020, 383, 1479-1480. [CrossRef]

2. Miller, I.F.; Becker, A.D.; Grenfell, B.T.; Metcalf, C.J.E. Disease and healthcare burden of COVID-19 in the United States. Nat. Med. 2020, 26, 1212-1217. [CrossRef] [PubMed]

3. Chu, D.K.; Kim, L.H.; Young, P.J.; Zamiri, N.; Almenawer, S.A.; Jaeschke, R.; Szczeklik, W.; Schünemann, H.J.; Neary, J.D.; Alhazzani, W. Mortality and morbidity in acutely ill adults treated with liberal versus conservative oxygen therapy (IOTA): A systematic review and meta-analysis. Lancet 2018, 391, 1693-1705. [CrossRef]

4. Barrot, L.; Asfar, P.; Mauny, F.; Winiszewski, H.; Montini, F.; Badie, J.; Quenot, J.P.; Pili-Floury, S.; Bouhemad, B.; Louis, G.; et al. Liberal or conservative oxygen therapy for acute respiratory distress syndrome. N. Engl. J. Med. 2020, 382, 999-1008. [CrossRef] [PubMed]

5. Vandenberg, O.; Martiny, D.; Rochas, O.; van Belkum, A.; Kozlakidis, Z. Considerations for diagnostic COVID-19 tests. Nat. Rev. Microbiol. 2020. [CrossRef]

6. Hopman, J.; Allegranzi, B.; Mehtar, S. Managing COVID-19 in low- and middle-income countries. JAMA 2020, 323, 1549-1550. [CrossRef]

7. Le Page, M. Home testing is no quick fix. New Sci. 2020, 245, 11. [CrossRef]

8. Weissleder, R.; Lee, H.; Ko, J.; Pittet, M.J. COVID-19 diagnostics in context. Sci. Transl. Med. 2020, 12. [CrossRef] [PubMed]

9. Storch, G.A. Diagnostic virology. Clin. Infect. Dis. 2000, 31, 739-751. [CrossRef]

10. Zhou, P.; Yang, X.L.; Wang, X.G.; Hu, B.; Zhang, L.; Zhang, W.; Si, H.R.; Zhu, Y.; Li, B.; Huang, C.L.; et al. A pneumonia outbreak associated with a new coronavirus of probable bat origin. Nature 2020, 579, 270-273. [CrossRef] [PubMed]

11. Jamshaid, H.; Zahid, F.; Din, I.u.; Zeb, A.; Choi, H.G.; Khan, G.M.; Din, F.u. Diagnostic and treatment strategies for COVID-19. AAPS PharmSciTech 2020, 21, 222. [CrossRef]

12. Zhang, W.; Du, R.H.; Li, B.; Zheng, X.S.; Yang, X.L.; Hu, B.; Wang, Y.Y.; Xiao, G.F.; Yan, B.; Shi, Z.L.; et al. Molecular and serological investigation of 2019-nCoV infected patients: Implication of multiple shedding routes. Emerg. Microbes Infect. 2020, 9, 386-389. [CrossRef]

13. Böger, B.; Fachi, M.M.; Vilhena, R.O.; Cobre, A.F.; Tonin, F.S.; Pontarolo, R. Systematic review with meta-analysis of the accuracy of diagnostic tests for COVID-19. Am. J. Infect. Control 2020. [CrossRef]

14. Candel, F.J.; Barreiro, P.; San Román, J.; Abanades, J.C.; Barba, R.; Barberán, J.; Bibiano, C.; Canora, J.; Cantón, R.; Calvo, C.; et al. Recommendations for use of antigenic tests in the diagnosis of acute SARS-CoV-2 infection in the second pandemic wave: Attitude in different clinical settings. Rev. Esp. Quimioter. 2020, 33, 466-484. [CrossRef] [PubMed]

15. Falzone, L.; Musso, N.; Gattuso, G.; Bongiorno, D.; Palermo, C.I.; Scalia, G.; Libra, M.; Stefani, S. Sensitivity assessment of droplet digital PCR for SARS-CoV-2 detection. Int. J. Mol. Med. 2020, 46, 957-964. [CrossRef] [PubMed]

16. Suo, T.; Liu, X.; Feng, J.; Guo, M.; Hu, W.; Guo, D.; Ullah, H.; Yang, Y.; Zhang, Q.; Wang, X.; et al. ddPCR: A more accurate tool for SARS-CoV-2 detection in low viral load specimens. Emerg. Microbes Infect. 2020, 9, 1259-1268. [CrossRef] [PubMed]

17. Alteri, C.; Cento, V.; Antonello, M.; Colagrossi, L.; Merli, M.; Ughi, N.; Renica, S.; Matarazzo, E.; Di Ruscio, F.; Tartaglione, L.; et al. Detection and quantification of SARS-CoV-2 by droplet digital PCR in real-time PCR negative nasopharyngeal swabs from suspected COVID-19 patients. PLOS ONE 2020, 15, e0236311. [CrossRef]

18. Huang, W.E.; Lim, B.; Hsu, C.C.; Xiong, D.; Wu, W.; Yu, Y.; Jia, H.; Wang, Y.; Zeng, Y.; Ji, M.; et al. RT-LAMP for rapid diagnosis of coronavirus SARS-CoV-2. Microb. Biotechnol. 2020, 13, 950-961. [CrossRef] 
19. Hadisi, Z.; Walsh, T.; Dabiri, S.M.H.; Seyfoori, A.; Hamdi, D.; Mirani, B.; Pagan, E.; Jardim, A.; Akbari, M. Management of Coronavirus Disease 2019 (COVID-19) Pandemic: From diagnosis to treatment strategies. Adv. Ther. 2021, 4, 2000173. [CrossRef]

20. Joung, J.; Ladha, A.; Saito, M.; Kim, N.G.; Woolley, A.E.; Segel, M.; Barretto, R.P.J.; Ranu, A.; Macrae, R.K.; Faure, G.; et al. Detection of SARS-CoV-2 with SHERLOCK One-Pot Testing. N. Engl. J. Med. 2020, 383, 1492-1494. [CrossRef]

21. Patchsung, M.; Jantarug, K.; Pattama, A.; Aphicho, K.; Suraritdechachai, S.; Meesawat, P.; Sappakhaw, K.; Leelahakorn, N.; Ruenkam, T.; Wongsatit, T.; et al. Clinical validation of a Cas13-based assay for the detection of SARS-CoV-2 RNA. Nat. Biomed. Eng. 2020, 4, 1140-1149. [CrossRef]

22. Broughton, J.P.; Deng, X.; Yu, G.; Fasching, C.L.; Servellita, V.; Singh, J.; Miao, X.; Streithorst, J.A.; Granados, A.; SotomayorGonzalez, A.; et al. CRISPR-Cas12-based detection of SARS-CoV-2. Nat. Biotechnol. 2020, 38, 870-874. [CrossRef] [PubMed]

23. Li, J.; Tao, Y.; Tang, M.; Du, B.; Xia, Y.; Mo, X.; Cao, Q. Rapid detection of respiratory organisms with the FilmArray respiratory panel in a large children's hospital in China. BMC Infect. Dis. 2018, 18, 510. [CrossRef]

24. Schmitz, J.E.; Tang, Y.-W. The GenMark ePlex $\left({ }^{\circledR}\right)$ : Another weapon in the syndromic arsenal for infection diagnosis. Future Microbiol. 2018, 13, 1697-1708. [CrossRef]

25. Scohy, A.; Anantharajah, A.; Bodéus, M.; Kabamba-Mukadi, B.; Verroken, A.; Rodriguez-Villalobos, H. Low performance of rapid antigen detection test as frontline testing for COVID-19 diagnosis. J. Clin. Virol. 2020, 129, 104455. [CrossRef]

26. Corman, V.M.; Haage, V.C.; Bleicker, T.; Schmidt, M.L.; Mühlemann, B.; Zuchowski, M.; Jó Lei, W.K.; Tscheak, P.; Möncke-Buchner, E.; Müller, M.A.; et al. Comparison of seven commercial SARS-CoV-2 rapid Point-of-Care Antigen tests. MedRxiv 2020. [CrossRef]

27. Dinnes, J.; Deeks, J.J.; Berhane, S.; Taylor, M.; Adriano, A.; Davenport, C.; Dittrich, S.; Emperador, D.; Takwoingi, Y.; Cunningham, J.; et al. Rapid, point-of-care antigen and molecular-based tests for diagnosis of SARS-CoV-2 infection. Cochrane Database Syst. Rev. 2021, 3, CD013705. [CrossRef] [PubMed]

28. La Marca, A.; Capuzzo, M.; Paglia, T.; Roli, L.; Trenti, T.; Nelson, S.M. Testing for SARS-CoV-2 (COVID-19): A systematic review and clinical guide to molecular and serological in-vitro diagnostic assays. Reprod. Biomed. Online 2020, 41, 483-499. [CrossRef]

29. Klabbers, R.E.; Muwonge, T.R.; Ayikobua, E.; Izizinga, D.; Bassett, I.V.; Kambugu, A.; Tsai, A.C.; Ravicz, M.; Klabbers, G.; O'Laughlin, K.N. Health worker perspectives on barriers and facilitators of assisted partner notification for HIV for refugees and ugandan nationals: A mixed methods study in West Nile Uganda. AIDS Behav. 2021. [CrossRef]

30. Tang, M.S.; Hock, K.G.; Logsdon, N.M.; Hayes, J.E.; Gronowski, A.M.; Anderson, N.W.; Farnsworth, C.W. Clinical performance of two SARS-CoV-2 serologic assays. Clin. Chem. 2020, 66, 1055-1062. [CrossRef]

31. Hanson, K.E.; Caliendo, A.M.; Arias, C.A.; Englund, J.A.; Hayden, M.K.; Lee, M.J.; Loeb, M.; Patel, R.; Altayar, O.; El Alayli, A.; et al. IDSA guidelines on the diagnosis of COVID-19: Serologic Testing. Clin. Infect. Dis. 2020. [CrossRef]

32. Santini, M.; Zupetic, I.; Viskovic, K.; Krznaric, J.; Kutlesa, M.; Krajinovic, V.; Polak, V.L.; Savic, V.; Tabain, I.; Barbic, L.; et al. Cauda equina arachnoiditis-A rare manifestation of West Nile virus neuroinvasive disease: A case report. World J. Clin. Cases 2020, 8, 3797-3803. [CrossRef] [PubMed]

33. Lijia, S.; Lihong, S.; Huabin, W.; Xiaoping, X.; Xiaodong, L.; Yixuan, Z.; Pin, H.; Yina, X.; Xiaoyun, S.; Junqi, W. Serological chemiluminescence immunoassay for the diagnosis of SARS-CoV-2 infection. J. Clin. Lab. Anal. 2020, 34, e23466. [CrossRef] [PubMed]

34. Castaldo, N.; Graziano, E.; Peghin, M.; Gallo, T.; D’Agaro, P.; Sartor, A.; Bove, T.; Cocconi, R.; Merlino, G.; Bassetti, M. Neuroinvasive West Nile Infection with an Unusual Clinical Presentation: A Single-Center Case Series. Trop. Med. Infect. Dis. 2020, 5. [CrossRef]

35. Lisboa Bastos, M.; Tavaziva, G.; Abidi, S.K.; Campbell, J.R.; Haraoui, L.-P.; Johnston, J.C.; Lan, Z.; Law, S.; MacLean, E.; Trajman, A.; et al. Diagnostic accuracy of serological tests for covid-19: Systematic review and meta-analysis. BMJ 2020, $370, \mathrm{~m} 2516$. [CrossRef] [PubMed]

36. Duong, Y.T.; Wright, C.G.; Justman, J. Antibody testing for coronavirus disease 2019: Not ready for prime time. BMJ 2020, 370, m2655. [CrossRef] [PubMed]

37. Infantino, M.; Grossi, V.; Lari, B.; Bambi, R.; Perri, A.; Manneschi, M.; Terenzi, G.; Liotti, I.; Ciotta, G.; Taddei, C.; et al. Diagnostic accuracy of an automated chemiluminescent immunoassay for anti-SARS-CoV-2 IgM and IgG antibodies: An Italian experience. J. Med Virol. 2020, 92, 1671-1675. [CrossRef]

38. Chen, S.-Y.; Lee, Y.-L.; Lin, Y.-C.; Lee, N.-Y.; Liao, C.-H.; Hung, Y.-P.; Lu, M.-C.; Wu, J.-L.; Tseng, W.-P.; Lin, C.-H.; et al. Multicenter evaluation of two chemiluminescence and three lateral flow immunoassays for the diagnosis of COVID-19 and assessment of antibody dynamic responses to SARS-CoV-2 in Taiwan. Emerg. Microbes Infect. 2020, 9, 2157-2168. [CrossRef] [PubMed]

39. Guan, W.J.; Ni, Z.Y.; Hu, Y.; Liang, W.H.; Ou, C.Q.; He, J.X.; Liu, L.; Shan, H.; Lei, C.L.; Hui, D.S.C.; et al. Clinical characteristics of coronavirus disease 2019 in China. N. Engl. J. Med. 2020, 382, 1708-1720. [CrossRef]

40. Higham, A.; Mathioudakis, A.G.; Vestbo, J.; Singh, D. COVID-19 and COPD: A narrative review of the basic science and clinical outcomes. Eur. Respir. Rev. 2020, 29, 200199. [CrossRef]

41. Luks, A.M.; Swenson, E.R. Pulse oximetry for monitoring patients with COVID-19 at home. potential pitfalls and practical guidance. Ann. Am. Thorac. Soc. 2020, 17, 1040-1046. [CrossRef]

42. Torjesen, I. Covid-19: Patients to use pulse oximetry at home to spot deterioration. BMJ 2020, 371, m4151. [CrossRef]

43. Mori, Y.; Nakashima, Y.; Kaneko, S.; Inoue, N.; Murakami, T. Risk factors for cardiac adverse events in infants and children with complex heart disease scheduled for Bi-ventricular repair: Prognostic value of pre-operative B-type natriuretic peptide and high-sensitivity troponin T. Pediatr. Cardiol. 2020, 41, 1756-1765. [CrossRef] 
44. Shah, S.; Majmudar, K.; Stein, A.; Gupta, N.; Suppes, S.; Karamanis, M.; Capannari, J.; Sethi, S.; Patte, C. Novel use of home pulse oximetry monitoring in COVID-19 patients discharged from the emergency department identifies need for hospitalization. Acad. Emerg. Med. 2020, 27, 681-692. [CrossRef] [PubMed]

45. Inada-Kim, M.; Chmiel, F.P.; Boniface, M.J.; Pocock, H.; Black, J.J.M.; Deakin, C.D. Validation of home oxygen saturations as a marker of clinical deterioration in patients with suspected COVID-19. MedRxiv 2020. [CrossRef]

46. Usul, E.; Şan, İ.; Bekgöz, B.; Şahin, A. Role of hematological parameters in COVID-19 patients in the emergency room. Biomark. Med. 2020, 14, 1207-1215. [CrossRef] [PubMed]

47. Zhang, B.; Zhou, X.; Qiu, Y.; Song, Y.; Feng, F.; Feng, J.; Song, Q.; Jia, Q.; Wang, J. Clinical characteristics of 82 cases of death from COVID-19. PLoS ONE 2020, 15, e0235458. [CrossRef]

48. Du, Y.; Tu, L.; Zhu, P.; Mu, M.; Wang, R.; Yang, P.; Wang, X.; Hu, C.; Ping, R.; Hu, P.; et al. Clinical features of 85 fatal cases of COVID-19 from Wuhan. A retrospective observational study. Am. J. Respir. Crit. Care Med. 2020, 201, 1372-1379. [CrossRef] [PubMed]

49. Tan, L.; Wang, Q.; Zhang, D.; Ding, J.; Huang, Q.; Tang, Y.Q.; Wang, Q.; Miao, H. Lymphopenia predicts disease severity of COVID-19: A descriptive and predictive study. Signal Transduct. Target. Ther. 2020, 5, 33. [CrossRef]

50. Lindsley, A.W.; Schwartz, J.T.; Rothenberg, M.E. Eosinophil responses during COVID-19 infections and coronavirus vaccination. J. Allergy Clin. Immunol. 2020, 146, 1-7. [CrossRef]

51. Li, H.; Huang, J.-B.; Pan, W.; Zhang, C.-T.; Chang, X.-Y.; Yang, B. Systemic Immune-Inflammatory Index predicts prognosis of patients with COVID-19: A retrospective study. Res. Sq. 2020. [CrossRef]

52. Fois, A.G.; Paliogiannis, P.; Scano, V.; Cau, S.; Babudieri, S.; Perra, R.; Ruzzittu, G.; Zinellu, E.; Pirina, P.; Carru, C.; et al. The systemic inflammation index on admission predicts in-hospital mortality in COVID-19 patients. Molecules 2020, $25,5725$. [CrossRef]

53. McElvaney, O.J.; Hobbs, B.D.; Qiao, D.; McElvaney, O.F.; Moll, M.; McEvoy, N.L.; Clarke, J.; O'Connor, E.; Walsh, S.; Cho, M.H.; et al. A linear prognostic score based on the ratio of interleukin-6 to interleukin-10 predicts outcomes in COVID-19. EBioMedicine 2020, 61. [CrossRef]

54. Herold, T.; Jurinovic, V.; Arnreich, C.; Lipworth, B.J.; Hellmuth, J.C.; von Bergwelt-Baildon, M.; Klein, M.; Weinberger, T. Elevated levels of interleukin-6 and CRP predict the need for mechanical ventilation in COVID-19. J. Allergy Clin. Immunol. 2020, 146, 128-136. [CrossRef]

55. Laguna-Goya, R.; Utrero-Rico, A.; Talayero, P.; Lasa-Lazaro, M.; Ramirez-Fernandez, A.; Naranjo, L.; Segura-Tudela, A.; CabreraMarante, O.; de Frias, E.R.; Garcia-Garcia, R. IL-6-based mortality risk model for hospitalized patients with COVID-19. J. Allergy Clin. Immunol. 2020, 146, 799-807. [CrossRef] [PubMed]

56. Luo, X.; Zhou, W.; Yan, X.; Guo, T.; Wang, B.; Xia, H.; Ye, L.; Xiong, J.; Jiang, Z.; Liu, Y.; et al. Prognostic value of c-reactive protein in patients with coronavirus 2019. Clin. Infect. Dis. 2020, 71, 2174-2179. [CrossRef] [PubMed]

57. Zhang, J.; Hao, Y.; Ou, W.; Ming, F.; Liang, G.; Qian, Y.; Cai, Q.; Dong, S.; Hu, S.; Wang, W.; et al. Serum interleukin-6 is an indicator for severity in 901 patients with SARS-CoV-2 infection: A cohort study. J. Transl. Med. 2020, 18, 406. [CrossRef] [PubMed]

58. Leisman, D.E.; Ronner, L.; Pinotti, R.; Taylor, M.D.; Sinha, P.; Calfee, C.S.; Hirayama, A.V.; Mastroiani, F.; Turtle, C.J.; Harhay, M.O.; et al. Cytokine elevation in severe and critical COVID-19: A rapid systematic review, meta-analysis, and comparison with other inflammatory syndromes. Lancet Respir. Med. 2020, 8, 1233-1244. [CrossRef]

59. Dhar, S.K.; Vishnupriyan, K.; Damodar, S.; Gujar, S.; Das, M. IL-6 and IL-10 as predictors of disease severity in COVID 19 patients: Results from Meta-analysis and Regression. MedRxiv 2020. [CrossRef]

60. Lazzaroni, M.G.; Piantoni, S.; Masneri, S.; Garrafa, E.; Martini, G.; Tincani, A.; Andreoli, L.; Franceschini, F. Coagulation dysfunction in COVID-19: The interplay between inflammation, viral infection and the coagulation system. Blood Rev. 2020, 100745. [CrossRef]

61. Wool, G.D.; Miller, J.L. The impact of COVID-19 disease on platelets and coagulation. Pathobiology 2020. [CrossRef] [PubMed]

62. Haimei, M.A. Pathogenesis and Treatment Strategies of COVID-19-Related Hypercoagulant and Thrombotic Complications. Clin. Appl. Thromb. Hemost. 2020, 26, 1076029620944497. [CrossRef] [PubMed]

63. Zhang, L.; Yan, X.; Fan, Q.; Liu, H.; Liu, X.; Liu, Z.; Zhang, Z. D-dimer levels on admission to predict in-hospital mortality in patients with Covid-19. J. Thromb. Haemost. 2020, 18, 1324-1329. [CrossRef]

64. Jin, X.; Duan, Y.; Bao, T.; Gu, J.; Chen, Y.; Li, Y.; Mao, S.; Chen, Y.; Xie, W. The values of coagulation function in COVID-19 patients. PLoS ONE 2020, 15, e0241329. [CrossRef] [PubMed]

65. Wang, L.; He, W.-B.; Yu, X.-M.; Hu, D.-L.; Jiang, H. Prolonged prothrombin time at admission predicts poor clinical outcome in COVID-19 patients. World J. Clin. Cases 2020, 8, 4370-4379. [CrossRef]

66. Di Micco, P.; Russo, V.; Carannante, N.; Imparato, M.; Cardillo, G.; Lodigiani, C. Prognostic value of fibrinogen among COVID-19 patients admitted to an emergency department: An Italian cohort study. J. Clin. Med. 2020, 9, 4134. [CrossRef]

67. Liu, Y.; Sun, W.; Guo, Y.; Chen, L.; Zhang, L.; Zhao, S.; Long, D.; Yu, L. Association between platelet parameters and mortality in coronavirus disease 2019: Retrospective cohort study. Platelets 2020, 31, 490-496. [CrossRef]

68. Tang, N.; Li, D.; Wang, X.; Sun, Z. Abnormal coagulation parameters are associated with poor prognosis in patients with novel coronavirus pneumonia. J. Thromb. Haemost. 2020, 18, 844-847. [CrossRef] 
69. Vardavas, C.I.; Mathioudakis, A.G.; Nikitara, K.; Stamatelopoulos, K.; Georgiopoulos, G.; Phalkey, R.; Leonardi-Bee, J.; Fernandez, E.; Carnicer-Pont, D.; Dimopoulos, M.A.; et al. A systematic review and meta-analysis of prognostic factors for adverse outcomes of SARS-CoV-2 in USA and Europe. Lancet Digit. Health 2021. in peer review.

70. Harrison, S.L.; Fazio-Eynullayeva, E.; Lane, D.A.; Underhill, P.; Lip, G.Y.H. Comorbidities associated with mortality in 31,461 adults with COVID-19 in the United States: A federated electronic medical record analysis. PLoS Med. 2020, 17, e1003321. [CrossRef]

71. Zhou, W.; Qin, X.; Hu, X.; Lu, Y.; Pan, J. Prognosis models for severe and critical COVID-19 based on the Charlson and Elixhauser comorbidity indices. Int. J. Med. Sci. 2020, 17, 2257-2263. [CrossRef]

72. Tuty Kuswardhani, R.A.; Henrina, J.; Pranata, R.; Anthonius Lim, M.; Lawrensia, S.; Suastika, K. Charlson comorbidity index and a composite of poor outcomes in COVID-19 patients: A systematic review and meta-analysis. Diabetes Metab. Syndr. Clin. Res. Rev. 2020, 14, 2103-2109. [CrossRef]

73. Mercola, J.; Grant, W.B.; Wagner, C.L. Evidence regarding Vitamin D and risk of COVID-19 and its severity. Nutrients 2020, 12. [CrossRef]

74. Grant, W.B.; Lahore, H.; McDonnell, S.L.; Baggerly, C.A.; French, C.B.; Aliano, J.L.; Bhattoa, H.P. Evidence that Vitamin D supplementation could reduce risk of influenza and COVID-19 infections and deaths. Nutrients 2020, 12. [CrossRef] [PubMed]

75. Papadopoulos, N.G.; Custovic, A.; Deschildre, A.; Mathioudakis, A.G.; Phipatanakul, W.; Wong, G.; Xepapadaki, P.; Agache, I.; Bacharier, L.; Bonini, M.; et al. Impact of COVID-19 on Pediatric Asthma: Practice Adjustments and Disease Burden. J. Allergy Clin. Immunol. Pract. 2020. [CrossRef]

76. Papadopoulos, N.G.; Mathioudakis, A.G.; Custovic, A.; Deschildre, A.; Phipatanakul, W.; Wong, G.; Xepapadaki, P.; Abou-Taam, R.; Agache, I.; Castro-Rodriguez, J.A.; et al. Childhood asthma outcomes during the COVID-19 pandemic: Findings from the PeARL multinational cohort. Allergy 2021. [CrossRef] [PubMed]

77. Carli, G.; Cecchi, L.; Stebbing, J.; Parronchi, P.; Farsi, A. Is asthma protective against COVID-19? Allergy 2021, 76, 866-868. [CrossRef] [PubMed]

78. Dastoli, S.; Bennardo, L.; Patruno, C.; Nistico, S.P. Are erythema multiforme and urticaria related to a better outcome of COVID-19? Dermatol. Ther. 2020, 33, e13681. [CrossRef]

79. Gong, J.; Ou, J.; Qiu, X.; Jie, Y.; Chen, Y.; Yuan, L.; Cao, J.; Tan, M.; Xu, W.; Zheng, F.; et al. A tool to early predict severe corona virus disease 2019 (COVID-19): A multicenter study using the risk nomogram in Wuhan and Guangdong, China. MedRxiv 2020. [CrossRef]

80. Islam, N.; Salameh, J.P.; Leeflang, M.M.; Hooft, L.; McGrath, T.A.; van der Pol, C.B.; Frank, R.A.; Kazi, S.; Prager, R.; Hare, S.S.; et al. Thoracic imaging tests for the diagnosis of COVID-19. Cochrane Database Syst. Rev. 2020, 11, CD013639. [CrossRef]

81. Bagnera, S.; Bisanti, F.; Tibaldi, C.; Pasquino, M.; Berrino, G.; Ferraro, R.; Patania, S. Performance of radiologists in the evaluation of the chest radiography with the use of a "new software score" in Coronavirus Disease 2019 pneumonia suspected patients. J. Clin. Imaging Sci. 2020, 10, 40. [CrossRef] [PubMed]

82. Yates, A.; Dempsey, P.J.; Vencken, S.; MacMahon, P.J.; Hutchinson, B.D. Structured reporting in portable chest radiographs: An essential tool in the diagnosis of COVID-19. Eur. J. Radiol. 2021, 134. [CrossRef] [PubMed]

83. Agrawal, V.; Yadav, S.K.; Sharma, D. Pre-operative CT Chest as a screening tool for COVID-19: An appraisal of current evidence. Br. J. Surg. 2020, 107, e596-e597. [CrossRef] [PubMed] 